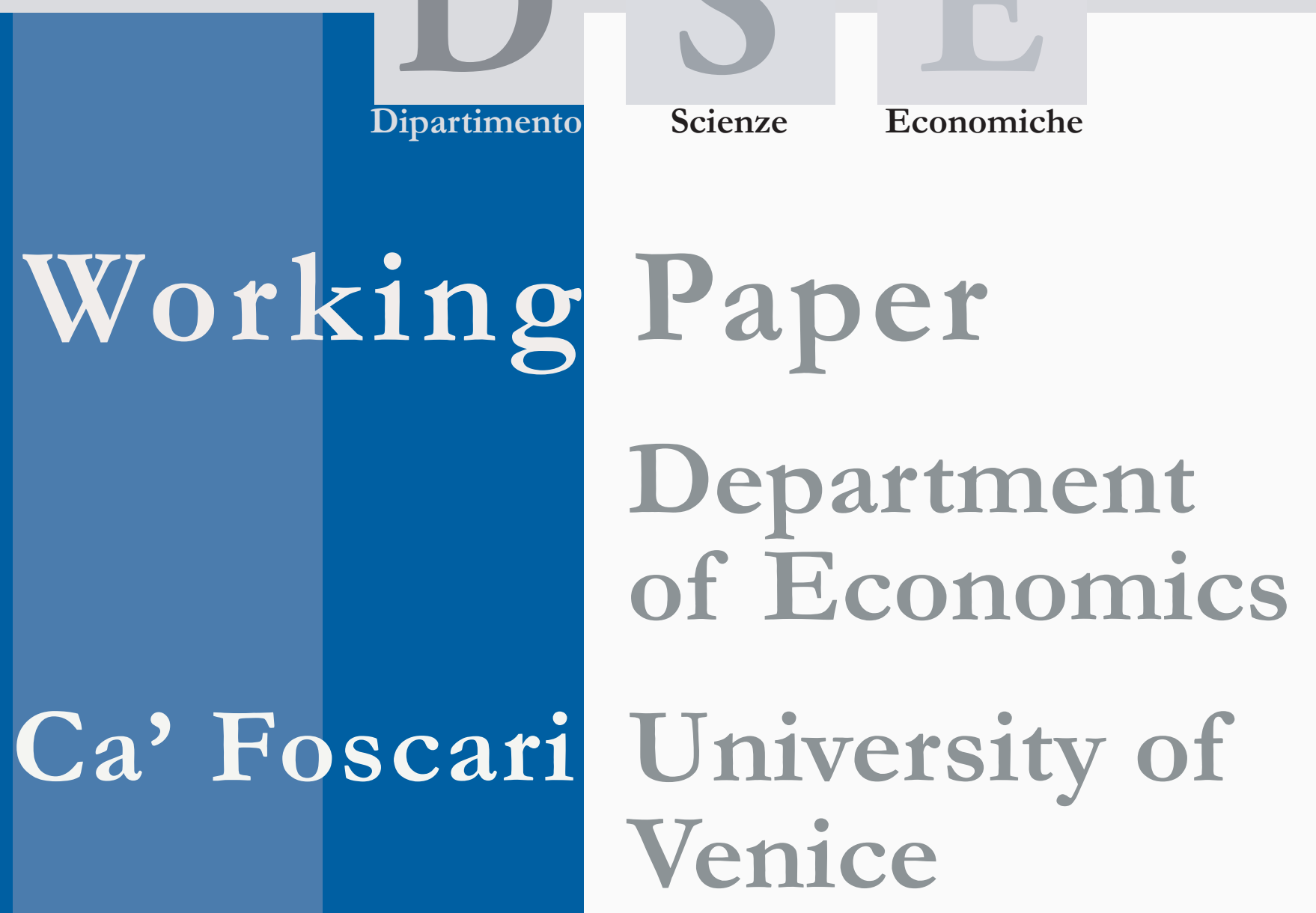

Giuseppe Tattara

Marco Valentini

The cyclical behaviour of job and worker flows 


\title{
The cyclical behaviour of job and worker flows
}

\author{
Giuseppe Tattara and Marco Valentini \\ Department of Economics \\ Università di Venezia
}

\begin{abstract}
This research exploits a large employer-level panel dataset in order to analyse employment and worker flows. Excess reallocation, the difference between worker and job flows at the firm level, is substantial and has a definite cyclical pattern.

Both accessions and separations are cyclical in contrast to the conventional wisdom that assumes separation to be countercyclical. Separations increase in upswing, following the accession increase, and decline in recession. Unemployment during recession is not, to a large extent, due to an increase in the rate at which workers separate from their employers, as traditionally assumed among macroeconomists, but to the decline in job creations.
\end{abstract}

Keywords: Job Flows, Worker Flows, Reallocation, Cyclical behaviour

JEL Codes: E24, E32, J21, J44

Address for correspondence: Giuseppe Tattara

Department of Economics Ca' Foscari University of Venice Cannaregio 873, Fondamenta S.Giobbe 30121 Venezia - Italy

Phone: (++39) 0412349148

Fax: (++39) 0412349176

e-mail: tattara@unive.it

This Working Paper is published under the auspices of the Department of Economics of the Ca' Foscari University of Venice. Opinions expressed herein are those of the authors and not those of the Department. The Working Paper series is designed to divulge preliminary or incomplete work, circulated to favour discussion and comments. Citation of this paper should consider its provisional character. 


\section{The cyclical behaviour of job and worker flows ${ }^{1}$.}

\section{Introduction.}

This paper analyses worker flows and job flows at the level of the employer. Worker flows are distinct from job flows: many contracting employers hire workers and many expanding employers fire workers and many workers leave expanding employers. Worker flows in excess of job flows are referred to as excess reallocation flows or churning flows: these are mainly job-to-job flows. The high level of such flows in Canada, Denmark, Estonia, France, Italy, Netherlands and in the United States, has been recently discussed (for a summary: Davis and Haltiwanger, 1999; Haltiwanger and Vodopivec, 2002).

The diversity of worker flows and job flows underlines the complexity of the search and reallocation process going on in the labour market and the task of the supporting institutions.

Both accessions and separations are cyclical in contrast to the conventional wisdom that assumes separation to be countercyclical. As a result excess reallocation is cyclical. Separations increase in upswing, following the accession increase, and decline in recession. Unemployment during recession is not, to a large extent, due to an increase in the rate at which workers separate from their employers but to the decline in job creations. In a similar vein a labour market that becomes more and more tight as time goes by, is characterised by an increasing turnover (both accessions and separations) and an increasing excess reallocation. The excess reallocation increase is largely independent from the labour market reforms that have attempted to make more flexible the Italian labour market in the nineties.

The paper has the following structure. Section 2 describes the data and defines the various measures of mobility: worker flows, job flows and excess reallocation flows. Section 3 provides some empirical evidence of these flows. The following

\footnotetext{
1 This research is part of the Miur project 1999-2001, n. 9913193479 and 2002-2003, n. 2001134473. The authors thank the participants to the EALE 2004 annual conference where the paper has been presented and to the workshop "Dynamics and Inertia in the Italian labour Market and Policy Evaluation", San Servolo, Venice 2004 for their comments. They thank particularly Julia Lane for her written comments.

The VWH data-base used in the paper has been build with the help of a Miur financing and is available on request. All figures and tables in the paper are derived from the VWH data-base.
} 
sections 4 and 5 extend the study of the general relationship between total turnover and gross job turnover taking explicit account of the cycle and controlling for firms and workers heterogeneity, section 6 concludes.

\section{Data and definitions.}

Data. Recent works on job and worker flows exploit matched employer-worker data to examine whether worker engagements and separations are related to job creations and destructions at the employer level. Studies cover various countries and sectors and span from the late seventies to mid nineties. Some studies rely on a quarterly frequency and some on annual frequency (Leonard, 1993; Burgess, 2000; 2001; Bingley, 2000; Abowd, 1999; Picot, 2001).

The ideal dataset for analysing the divergence between worker and job flows is provided by the universe of employers matched by the universe of workers, because job flows are defined on the employer behaviour over time. We are able to exploit a long panel of such data. The longitudinal panel VWH used in this research is constructed from the administrative records of the Italian Social Security System (Inps). It refers to the entire population of employees and workers in two provinces, Treviso and Vicenza, of an Italian region, Veneto. The database covers each single plant and each single individual employed in the private sector (no state and local government, with few exceptions) except for those who are self-employed, farm workers and people receiving no salary.

Veneto provides a useful laboratory because of the large presence of small firms, indeed the average establishment size is 13 employees and half of the employee stock is not subject to protection against dismissal as stated by art. 18 of the Statuto dei lavoratori ${ }^{2}$, a alleged strong element of rigidity in the Italian labour

\footnotetext{
2 Statuto dei lavoratori is the name given to Law No. 300 of May 20, 1970, containing "rules on the protection of the freedom and dignity of workers and of trade union freedom and union activity in the workplace, and rules on the public employment service". The law was intended to promote the presence of trade unions at company level.

The Statuto differs from parallel European legislation in that it emphasizes protection of the rights of the individual. These provisions forbid, for instance, the use of private police in the workplace, personal searches, the abuse of disciplinary power, discriminatory behavior on the grounds of union membership or activity and so on. As far as trade union activity, the Statute grants a series of prerogatives to plant-level union structures appointed within the framework of trade union organizations that are signatories to collective agreements. Part III and Article 18 of the Statute apply to work/production units in the industrial and commercial sector with more than 15 employees and require the employer to reinstate employees who have been dismissed without justifiable reason. The law No. 108 of May 10, 1990 has partially changed the termination of the employment relationship.
} 
market. For a decade Veneto has been also a full employment region with a positive rate of job creation in manufacturing, compared to a negative national rate and positive migration flows. It is a dynamic manufacturing territory endowed with considerable elements of flexibility.

The central role played by manufacture (garments, mechanical goods, goldsmiths, leather, textile, furniture and plastics) induces to concentrate the present work on manufacturing employment. The stock of manufacturing workers in the two Veneto provinces of Treviso and Vicenza has varied between 194.000 employees in the early eighties and 233.000 employees in 1996, with a yearly positive average rate of variation of $1.4 \%$. The average rate of growth in employment is the result of a marked increase in white collars and women (Occari, Tattara and Volpe, 1997; 2001, p.18-22).

The VWH longitudinal panel has records on establishment and worker flows from 1982 to 1997, a rather long period of time, compared with other studies of the same kind; employers are classified in the three-digit ATECO 1981 standard classification (Revelli, 1994; Rapiti, 1998). The period of time covered by the database allows us to discuss the role of quits and layoffs, hires and turnover in relation to two expansionary cycles: 1984-1990 and 1993-1997.

VWH data include register-based information on all establishments and employees that have been hired by those establishments for at least one day during the period of observation, independent of the workers place of residence and taking into account the occupational spells out of Treviso and Vicenza as well. The unit of observation is the employer-day; such information is used to build a monthly history of the working life of each employee. Employers are identified by their identification number, which changes if ownership, in a strict sense, changes. This has been amended and any time more than $50 \%$ of all employees are taken over by the new legal employer, the employment spell is said to be continuing. Similarly, if there are short breaks in the employment spell, as long as the worker continues at the old employer, his spell is considered uninterrupted ${ }^{3}$.

3 A 'cleaned' social security archive has been used. The engagements/separations and the creations/destructions that are due to a change in the unit that pays the social security contribution not matched by a corresponding change of the working population assessed at the establishment 
Data include all individual employment spells with an employer, of whatever duration, and this probably results in a lot of very short spells. Although short spells characterize the average job, they are concentrated on young workers, while long spells characterize the mature workers' current experience.

All employment size are considered, because our territory is characterized by a multitude of very small units (establishments with $\leq 5$ employees account for almost $12 \%$ of the total manufacturing employment). ${ }^{4}$ These are two reasons but certainly not the only reasons that explain comparatively high mobility flows.

Definitions. Engagements measure new hires. Separations measure terminated contracts, i.e. quits and layoffs. Both measures are defined in continuous time. A job is a position filled by a worker. It refers, generally, to an establishment. ${ }^{5}$

Worker total turnover (TT) is defined as the total number of accessions (a) to a job or separations (s) from a job in the economy in a definite time interval ${ }^{6}$. The turnover ratio is defined as the ratio between turnover and the number of individuals exposed to the turnover risk $(\mathrm{N})$, i.e. the number of individuals, that at any moment in the time period, have shown as employees: worker flows (the numerator) are meaningfully compared to the whole set of workers that are potential candidates for originating such flows (Anastasia, Gambuzza and Rasera, 2000).

$\mathrm{N}$ is computed as the stock at the beginning of the period + accessions in the period of employees still employed at the end of the period + temporary accessions in the period (neither part of the initial stock nor of the final). Our index diverges from the indexes commonly used in turnover studies, whose

level are defined as 'spurious' and have been deleted. This has lead to a reduction of $9 \%$ of total engagements and separations in manufacturing. The complex matching procedure is explained in Occari and Pitingaro (1997). This procedure is common practice among people working with social security data. For a similar procedure, see Bingley and Westergård-Nielsen (2002).

${ }^{4}$ The absolute importance of small establishments makes the comparison with other countries doubtful; for example in our territory the percentage of employment in establishments with $\geq 100$ employee is $27 \%$ while in Denmark is more than $40 \%$ and is still larger in the United States. On the uncertain meaning of the mobility measures for small establishments, see Tattara and Valentini (2003).

${ }^{5}$ Social security contributions can be paid by the firm or, in case of a firms with more than one permanent establishment, by the establishment. The firm has nonetheless the possibility to centralize social security payments.

${ }^{6}$ Every worker can access and separate several times in the year; Gross Worker Turnover is the ratio between the number of workers that have 1 or more accessions and/or separations in the interval and the employee flow. GWT is not referred to directly in this paper. 
denominator is a measure of employment: past employment, current employment or an average of the two (Davis and Haltiwanger, 1999).

$\mathrm{TT}=\frac{1}{\mathrm{~N}}(\mathrm{a}+\mathrm{s})$

An important dynamic aspect of economic growth is due to the growth and decline of firms and establishments. In every industrial sector firms create jobs and firms destruct jobs. Creation and destruction frequently coexist in subunits (Boeri, 1996; Davis and Haltiwanger, 1996; Leonard and von Audenrode 1999). Job turnover refers to gross changes of positions and not to changes in employment contracts. It is measured by the sum of job creations and destructions at the establishment level, in a sector or in the whole system, in a definite time interval. A job created means the addition of an extra employee to the stock of workers; a job destroyed means a unit reduction in employment, both measured at the establishment level. Their sum, in absolute terms, is the magnitude of the job flow. Changes in jobs are influenced by economic growth, business cycle, structural change and competition between industries.

Gross job turnover $(\mathrm{GJT})$ is computed by adding up job creations $\left(\mathrm{c}_{\mathrm{j}}\right)$ and job destructions $\left(\mathrm{d}_{\mathrm{i}}\right)$, in absolute value, at the establishment level in the time unit. Establishments are labelled by $j, j=1, \ldots, F$. The rate of job turnover or gross job turnover is the ratio between the sum of creations and destructions, in absolute value, computed at the plant level, and the number of individuals exposed to the turnover risk $(\mathrm{N})$.

$G J T=\frac{1}{N} \sum_{j=1}^{F}\left(c_{j}+d_{j}\right)$

A positive worker turnover can take place even without any job turnover. Assume jobs and employment totally fixed, work turnover is nonetheless positive because of the natural worker mobility due to retirements and new entrances.

The relation between worker, job turnover and the net employment variation is as follows:

$\mathrm{a}-\mathrm{s}=\sum_{\mathrm{j}=1}^{\mathrm{F}}\left(\mathrm{c}_{\mathrm{j}}-\mathrm{d}_{\mathrm{j}}\right)=\Delta \mathrm{E}$ 
$\mathrm{TT} \geq \mathrm{GJT} \geq \Delta \mathrm{E}$

The difference between accessions and separations is equal to the difference between creations and destructions and measures the net growth of the employment stock. Although in many contemporary economic systems the increase in employment is negligible, this is the result of the creation of many new jobs and of the parallel process of destruction.

Only total turnover is defined non-ambiguously in relation to the adopted time periodization: job turnover decreases as the time period extends because transitions of temporary nature (those which compensate in the time interval) are not taken into account and the longer the period, the more numerous are the temporary transitions. Worker and job turnover match perfectly only when time is represented as a continuous process (Schettkat, 1996, p.19) ${ }^{7}$. All turnover measures depend on the size of the establishments, as a bigger size internalizes many changes between jobs that are not captured by the measure adopted.

Worker flows have two components: those that are an immediate consequence of job creation and destruction and those that are in excess of these flows ${ }^{8}$. The second component is computed as a residue and is referred to excess reallocation flow.

Excess reallocation is variously defined. The general definition is that of replaced quits or of contemporaneous hirings and firings: in both cases excess reallocation expresses the re-evaluation of a job match, initiated either by the employee or by the employer. The word reallocation means that the employer or the employee revise their past decisions or reallocate, while remaining in the same state. The worker moves to a different employer but remains employed: a job to job transition. The employer keeps the same employment level but reshapes his firm's

\footnotetext{
${ }^{7}$ According to our calculations, taking into account the year 1996, the sum of job creations and destructions counted every quarter, at the 3 digit level, amounts to 122.000 , while job creations and destructions counted yearly are just half of that: 62.000 jobs. 30.000 jobs are temporary jobs, i.e. jobs which are created and destroyed during the year 1996.

8 Basically reallocation flows are in excess of flows due to firms' demography (creation and destruction) although a more coherent definition would take into direct account also workers' demography, as human beings birth and die as well. Flows due to human replacement are instead included in reallocation flows, according to the standard definition, on the ground that they are "replaced quits" as well.
} 
skill mix through parallel hiring and firing (Burgess et al., 2000, p.79). Excess reallocation is defined as the difference between worker and job turnover flows'.

$\mathrm{CH}=\mathrm{TT}-\mathrm{GJT}$

\section{Empirical evidence.}

Total accessions and separations are very large: on average accessions constitute $21 \%$ and separations $20 \%$ of the number of subjects exposed to the mobility risk $\left(24 \%\right.$ and $23 \%$ of the employee stock value $\left.{ }^{10}\right)$. A mean worker flow (hires plus separations) rate of $41 \%$ ( $34 \%$ in firms $>5$ employee) indicates a vast amount of worker reallocation. Approximately one in 2.5 job matches either forms or breaks up each year.

The standard deviation of accessions through time almost doubles the standard deviation of separations: firms face the cycle through variation in accessions more than in separations (table 1).

Figure 1. Accessions, separations and excess reallocation

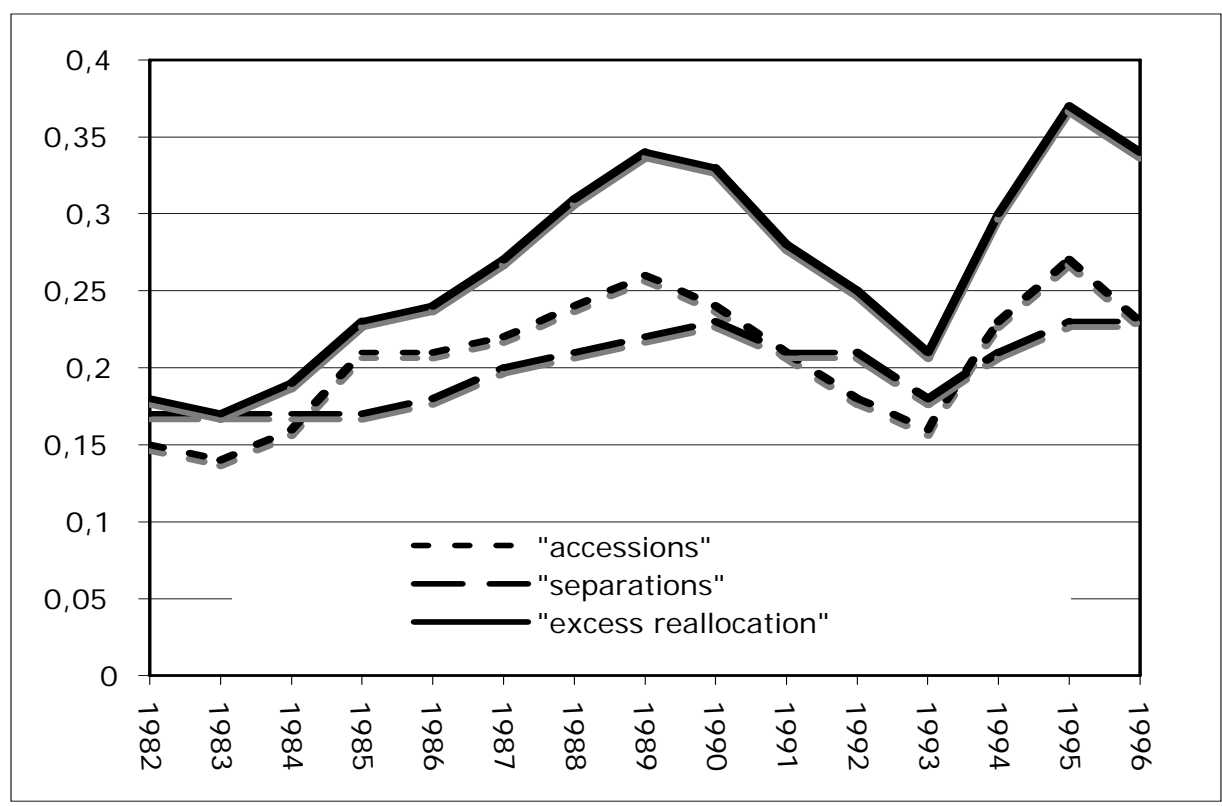

9 The last equation is able to capture the reallocation of workers over the same job, but not the reallocation of job over the same workers. In order to capture both kind of churning we need to use a more structured definition such as vacancy chain model, see Akerlof et al., 1988; Contini et al., 1997.

${ }^{10}$ Value in brackets refer to the stock value- and not to the exposed - in order to make international comparisons possible. 
The rate of job creation is $7.4 \%$, and $6.6 \%$ is the rate of job destruction (average 1982-96). Job inflows and outflows leave a positive balance that measures net employment growth in the economy. About one-fourth of the jobs created in a year are in new firms. A large proportion (one-third) of the jobs that are destroyed are in a firm that dies. Job creation constitutes $36 \%$ of total accessions, on average. There are considerable differences over time in the ratio of accessions that are due to job creations. In the boom years (1981-1989) 39\% of accessions were due to job creations, while only $31 \%$ of accessions were due to job creations in 1990-1992, the declining side of the cycle. Job destruction makes up $34 \%$ of separations, on average; in the slack years $40 \%$ of separations are due to disappearance of jobs against $30 \%$ in the boom years.

The variability of job creations is equal to the variability of job destructions. Job reallocation rate, on average $14 \%$ (16\% of the employee stock value) looks rather low in comparison with values reported by other studies, taken into account that our dataset covers all size establishments and that Veneto manufacturing has considerably reshuffled its sectors, moving positively from apparel to mechanics ${ }^{11}$. How large is the fraction of all reallocations due to job reallocation? An analysis of the distribution of worker and job flows reveals a large amount of excess reallocation.

\footnotetext{
${ }^{11}$ Lower values have been computed by Leonard and van Audenrode (1993) for Belgium and by Gerlach and Wagner (1993) for Lower Saxony, but the dataset covers only large establishments. Average job reallocation was 23\% (all size establishments) in Denmark by Albœk and Sørensen (1998).
} 
Table 1. Worker and job flows in Veneto manufacturing.

\begin{tabular}{|c|c|c|c|c|c|c|c|c|c|c|c|}
\hline & $a / N$ & $\mathrm{~s} / \mathrm{N}$ & $\mathrm{TT}$ & $\mathrm{c} / \mathrm{N}$ & $\mathrm{d} / \mathrm{N}$ & GJT & $\mathrm{CH}$ & $\mathrm{CH} / \mathrm{TT}$ & $\begin{array}{c}\text { emplo } \\
\text { yees }\end{array}$ & $\begin{array}{c}\text { unempl } \\
\text { oyment } \\
\text { rate }\end{array}$ & n. firms \\
\hline 1982 & 0,15 & 0,17 & 0,32 & 0,06 & 0,08 & 0,13 & 0,18 & 0,57 & 193505 & 0,067 & 10882 \\
\hline 1983 & 0,14 & 0,17 & 0,31 & 0,05 & 0,09 & 0,14 & 0,17 & 0,54 & 185989 & 0,078 & 10741 \\
\hline 1984 & 0,16 & 0,17 & 0,33 & 0,07 & 0,07 & 0,14 & 0,19 & 0,57 & 184164 & 0,090 & 11292 \\
\hline 1985 & 0,21 & 0,17 & 0,38 & 0,09 & 0,06 & 0,15 & 0,23 & 0,61 & 191032 & 0,084 & 12319 \\
\hline 1986 & 0,21 & 0,18 & 0,38 & 0,09 & 0,06 & 0,15 & 0,24 & 0,62 & 196304 & 0,077 & 12922 \\
\hline 1987 & 0,22 & 0,20 & 0,42 & 0,09 & 0,06 & 0,15 & 0,27 & 0,64 & 203491 & 0,074 & 13601 \\
\hline 1988 & 0,24 & 0,21 & 0,45 & 0,09 & 0,06 & 0,15 & 0,31 & 0,68 & 210478 & 0,068 & 14268 \\
\hline 1989 & 0,26 & 0,22 & 0,48 & 0,09 & 0,05 & 0,14 & 0,34 & 0,70 & 219433 & 0,058 & 14759 \\
\hline 1990 & 0,24 & 0,23 & 0,47 & 0,07 & 0,06 & 0,14 & 0,33 & 0,71 & 224729 & 0,047 & 14910 \\
\hline 1991 & 0,21 & 0,21 & 0,41 & 0,06 & 0,07 & 0,13 & 0,28 & 0,68 & 224483 & 0,046 & 14433 \\
\hline 1992 & 0,18 & 0,21 & 0,39 & 0,06 & 0,08 & 0,14 & 0,25 & 0,65 & 219097 & 0,055 & 14118 \\
\hline 1993 & 0,16 & 0,18 & 0,34 & 0,06 & 0,08 & 0,14 & 0,21 & 0,60 & 213251 & 0,054 & 13213 \\
\hline 1994 & 0,23 & 0,21 & 0,44 & 0,08 & 0,06 & 0,14 & 0,30 & 0,69 & 220548 & 0,062 & 13707 \\
\hline 1995 & 0,27 & 0,23 & 0,50 & 0,09 & 0,05 & 0,13 & 0,37 & 0,74 & 229695 & 0,056 & 14186 \\
\hline 1996 & 0,23 & 0,23 & 0,46 & 0,07 & 0,06 & 0,13 & 0,34 & 0,73 & 233481 & 0,054 & 14122 \\
\hline mean & 0,21 & 0,20 & 0,41 & 0,07 & 0,07 & 0,14 & 0,27 & 0,65 & 209979 & 0,065 & 13298 \\
\hline st.dev & 0,04 & 0,02 & 0,06 & 0,01 & 0,01 & 0,01 & 0,06 & 0,06 & & & \\
\hline
\end{tabular}

Unemployment figures are from Veneto Lavoro, various issues

The average value of $35 \%$ ( $32 \%$ in firms $>5$ employee, over the stock value) of worker flows accounted for by job flows can be compared with the estimate of $35 \%-56 \%$ by Davis and Haltiwanger (1992), 24\% by Anderson and Mayer (1994) and by $38 \%$ by Burgess, Lane and Stevens $(2000)^{12}$.

Total worker turnover is the sum of a job reallocation rate of $14 \%$ and an excess reallocation rate of $27 \%$. Excess reallocation flows account for $65 \%$ of all worker flows, peaking $74 \%$ in boom years and in recent years, with a low of $60 \%$ in the slack year 1993 and in the early eighties. The very high excess reallocation rate indicates a large amount of worker mobility over and above that occasioned by job reallocation. Data show that excess reallocation declines with the size of the employer (both worker and job reallocation decline) but is not related to the age of the firms, apart from the huge flows during the first couple of years of activity. On the whole excess reallocation flows are important throughout the age and size distribution of firms, but bigger firms have a higher excess reallocation over

\footnotetext{
${ }^{12}$ Such comparisons look exciting but hide serious pitfalls. Sample coverage and business units are often differently defined. Ownership and organizational changes vary across different datasets and are differently dealt with. The roles played by institutions are different, so different are the wage policy and job security provisions in different countries and these reflect immediately in the magnitude of flow measures. See Davis and Haltiwanger (1999, p.1753).
} 
turnover as in Burgess Lane and Stevens (2000). Our figures are almost double the rates reported by Burgess Lane and Stevens, for a comparable firm size and age, once the flow rates are rendered homogeneous (referring our numerators to the stock value). In our population almost $65 \%$ of all firms faced a worker turnover rate that was made by $50 \%$ or more by excess reallocation and half of the firms faced a turnover made by $75 \%$ by excess reallocation (on the importance of job to job transitions, Nagypal, 2004; 2005a; 2005b; Shimer,2005a; 2005b). This means that half of the firms of the entire population were affected by excess reallocation flows of very high magnitude. The percentage of firms affected by high excess reallocation flows has increased through time as the labour market has become more tight and has followed closely the unemployment cycle with opposite sign. Firms with high reallocation flows $(>50 \%)$ have moved from $50 \%$ at the beginning of the period to $63 \%$ at the 1990 peak, have dropped to $53 \%$ in the low 1993 to remount to $64 \%$ in $1996^{13}$.

\footnotetext{
${ }^{13}$ The percentage refers to firms having a positive TT.
} 
Table.2. Job and worker reallocation in manufacturing per firm's dimension and age.

\begin{tabular}{|l|r|r|r|r|r|r|r|r|r|r|}
\hline \multirow{2}{*}{} & \multicolumn{2}{|c|}{ TT } & \multicolumn{2}{c|}{ GJT } & \multicolumn{3}{|c|}{ CH } & \multicolumn{3}{c|}{ CH/TT } \\
\cline { 2 - 10 } & 1982 & 1996 & 1982 & 1996 & 1982 & 1996 & 1982 & 1996 \\
\hline Dimension & 0,63 & 0,63 & 0,32 & 0,26 & 0,31 & 0,37 & 0,50 & 0,59 \\
\hline Employment $\leq 5$ & 0,47 & 0,52 & 0,19 & 0,15 & 0,28 & 0,37 & 0,60 & 0,71 \\
\hline $5<$ Employment $\leq 15$ & 0,31 & 0,47 & 0,12 & 0,11 & 0,19 & 0,36 & 0,61 & 0,77 \\
\hline $15<$ Employment $\leq 49$ & 0,22 & 0,38 & 0,08 & 0,08 & 0,15 & 0,30 & 0,66 & 0,78 \\
\hline $49<$ Employment $\leq 99$ & 0,21 & 0,33 & 0,09 & 0,06 & 0,12 & 0,27 & 0,57 & 0,81 \\
\hline $99<$ Employment $\leq 199$ & 0,14 & 0,27 & 0,06 & 0,06 & 0,07 & 0,21 & 0,55 & 0,78 \\
\hline Employment $>199$ & & & & & & & & 0,68 \\
\hline Age & 0,46 & 0,59 & 0,20 & 0,19 & 0,27 & 0,40 & 0,57 & 0,68 \\
\hline $1 \leq$ years $<3$ & 0,41 & 0,38 & 0,15 & 0,11 & 0,26 & 0,27 & 0,63 & 0,71 \\
\hline $3 \leq$ years $<8$ & & 0,40 & & 0,11 & & 0,29 & & 0,73 \\
\hline $8 \leq$ years $\leq 21$ & & 0,45 & & 0,10 & & 0,35 & & 0,77 \\
\hline years $>21$ & & &
\end{tabular}

The number of employee is the denominator in the turnover formula, i.e. employees exposed to turnover risk. The firm's age 3-7 is 3-6 for 1982.

\section{Excess reallocation flows.}

Figure 2 provides a graphical presentation of the TT-GJT relation, following Burgess Lane and Stevens (2000, p.491). The upper part of the plane represents the SLL with positive excess reallocation (TT $\geq$ GJT). Assume, as a starting point, a firm with growth rate equal zero but a positive excess reallocation level (A), basically due to job to job transitions independent of employment net variations. In order to grow (job creation) firm A can pursue two strategies 1) increase accessions and have an higher turnover, i.e. move to (B); 2) decrease separations and have a lower turnover, move to $(\mathrm{C})$. In order to decline (job destruction) the conceivable strategies are 1) increase separations and have a higher turnover, move to (D); 2) decrease accessions and have a lower turnover, move to (E). 
Figure 2. Relationship between TT and the firm's GJT.

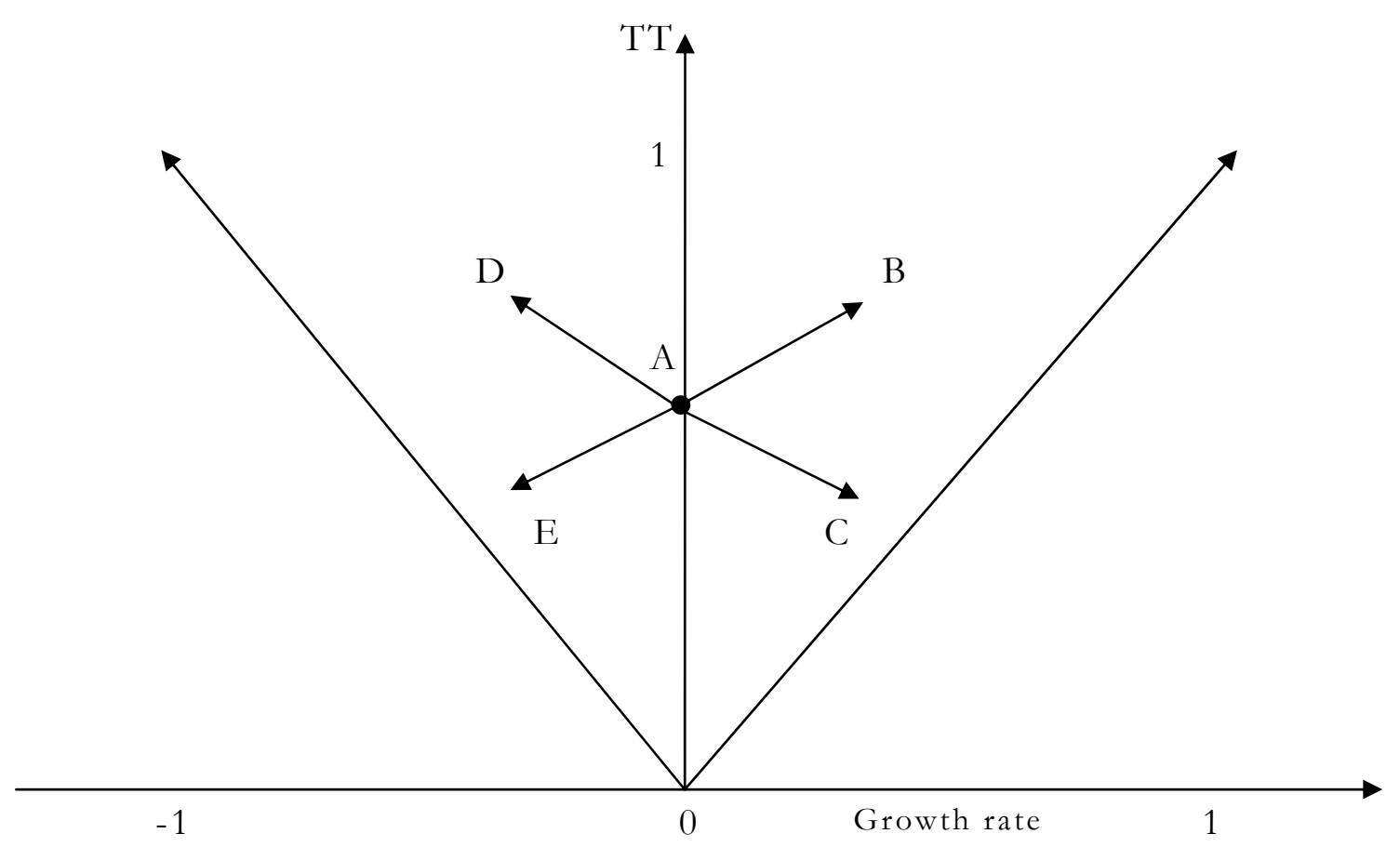

Growth rate absolute value is represented by GJT. Figures 3 and 4 represent, in the TTxGJT plane, the empirical relation between total flow and job flow rates in 1982 and 1996 for continuing employers. Various considerations follow. First, a lot of firms with modest growth rates have a widely dispersed pattern of worker flows and, as a consequence, various excess reallocation levels (the central part of the plot): this dispersion reflects the heterogeneity between workers and jobs and the firms' policy aiming at reducing labour costs via short term/seasonal contracts as well. Second, high job flows (high growth rates, both positive and negative) tend to exhaust total flows, leaving a modest excess reallocation: rapidly growing firms provide a stimulating environment to the workers, and entrepreneurs prefer to delay the possible adjustment to more quiet periods. Third, excess reallocation flows are, on the whole, much higher in 1996 than in 1982: the dark core of the plot is larger in figure 2 than in figure 3 , a clear sign of a tighter labour market in more recent years and of firm's recourse to shorter labour contracts. 
The inferior linear boundary of the TTxGJT plot reflects TT $\geq$ GJT. The superior linear boundary is due to $\mathrm{TT}+\mathrm{GJT} \leq 2$; TT + GJT $=((\mathrm{a}+\mathrm{s})+(\mathrm{a}-$ s)) $/ \mathrm{N}=2 \mathrm{a} / \mathrm{N}$, as $\max (\mathrm{a})=\mathrm{N} \Rightarrow \mathrm{TT}+\mathrm{GJT} \leq 2$. These two conditions shape a triangular SLL.

Figure 3. Total turnover and Gross job flows at the establishment level. 1982.

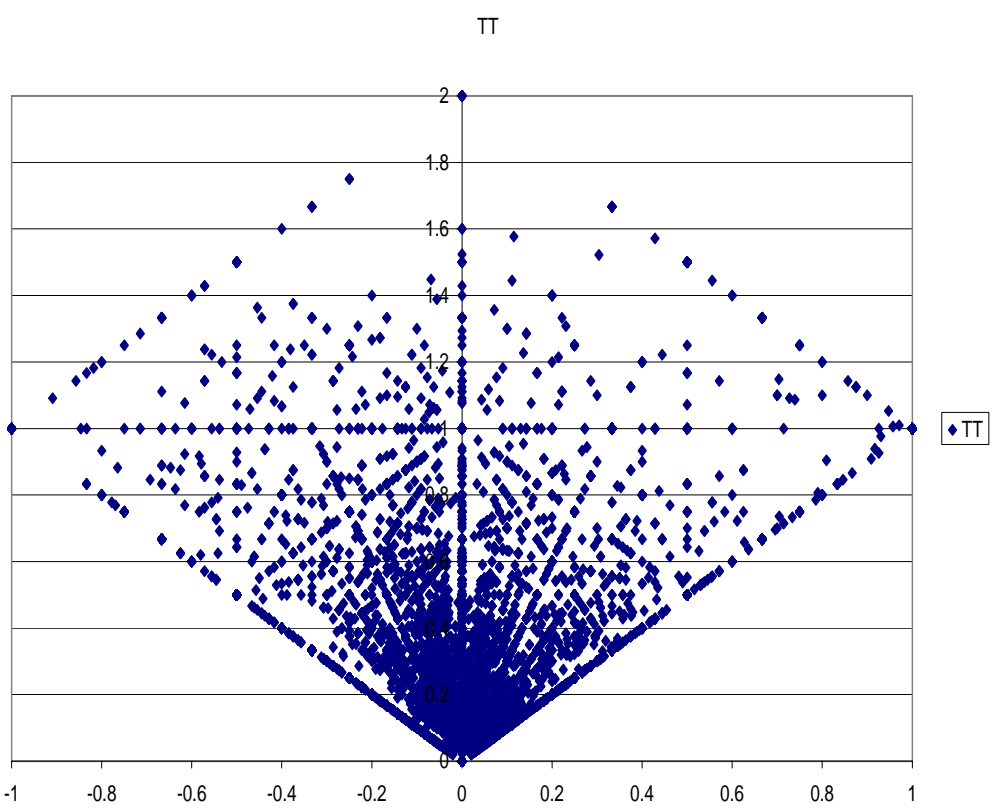

Figure 4. Total turnover and Gross job flows at the establishment level. 1996.

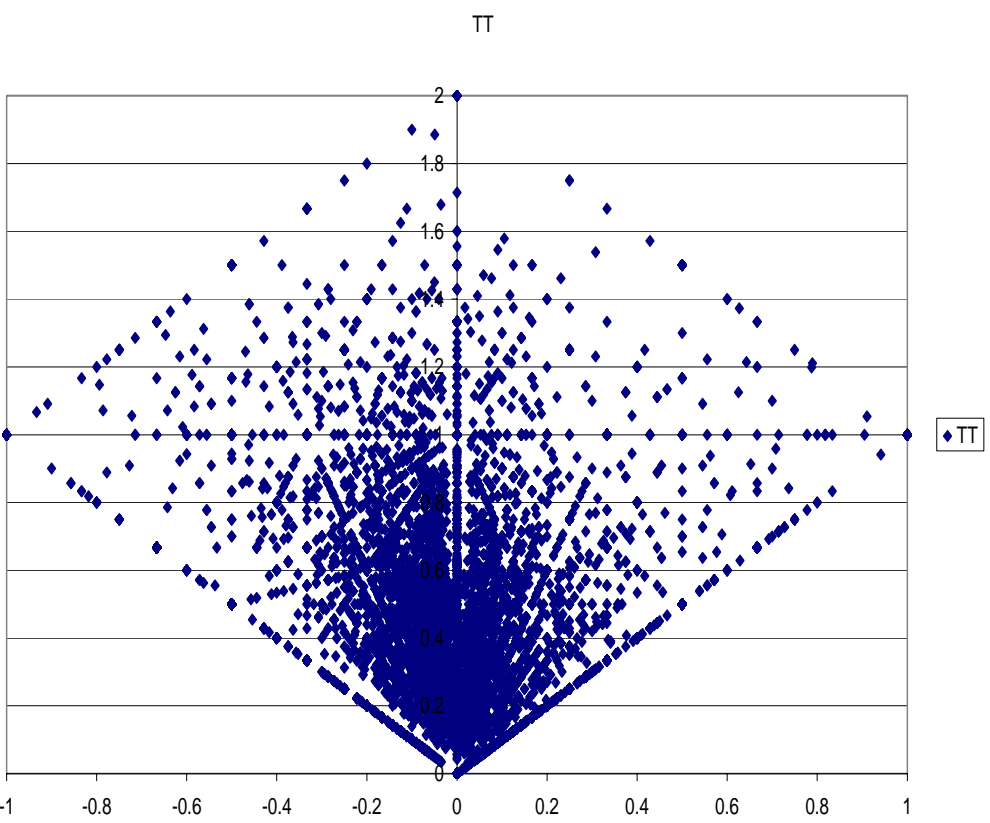




\section{Empirical specification, identification strategy and results.}

In this section we use a simple econometric model to evaluate the excess reallocation flows via the relation between total turnover and gross job turnover. Repeating the estimation for all the years of our study allows us to discuss the question of the cyclical behaviour of excess reallocation. The econometric specification adopted to answer this question is a simple model in which the probability of having a certain turnover rate depends on gross job turnover and on a set of demographic and other explanatory variables. Excess reallocation is indirectly estimated through the relation between worker and job turnover ${ }^{14}$.

The estimated equation is:

$$
\mathrm{TT}_{\mathrm{i}, \mathrm{t}}=\mathrm{b}_{0}+\mathrm{b}_{1} \mathrm{GJT}_{\mathrm{i}, \mathrm{t}}+\mathrm{bX}_{\mathrm{i}, \mathrm{t}}+\varepsilon_{\mathrm{i}, \mathrm{t}} \quad \mathrm{t}=1982, \ldots, 1996
$$

where $\mathrm{X}_{\mathrm{i}}$ is a vector of explanatory variables controlling for observable heterogeneity: dimension, firm age, artisan/non-artisan firm, sector, worker's gender, age, qualification (blue/white collar, time-limit, seasonal contracts and so on, as fully detailed in the Appendix), a set of territorial and yearly dummies is included as well.

The parameter of interest is $\mathrm{b}_{0}{ }^{15}$. It provides an assessment of the relation between total turnover and job turnover, i.e. excess reallocation: the bigger is the

\footnotetext{
14 Excess reallocation $(\mathrm{CH})$ is not directly estimated because $\mathrm{CH}$ is likely to be affected by "measurement error". In fact GJT does not identify individual jobs at the firm level; employment changes, particularly in large firms may not show up in newly created and newly destroyed jobs as observed in Davis and Haltiwanger (1996, p.91) and in Burgess, Lane and Stevens (2000, p.428), and the recourse to seasonal work, of a permanent character, does not show up in employment changes computed at yearly intervals (Anastasia, Gambuzza and Rasera, 2000). The uncertain meaning of GJT is reflected in "measurement error" in $\mathrm{CH}$, as $\mathrm{CH}=\mathrm{TT}$ - GJT, hence the regression of $\mathrm{CH}$ on GJT is likely to show up a negative coefficient induced by measurement error. $\mathrm{CH}$ is correlated with GJT, but job flows are understated and reallocation flows overstated (Burgess, 2001), i.e. $\mathrm{TT}_{\mathrm{j}}=\left(\overline{\mathrm{CH}}_{\mathrm{j}}+\alpha_{\mathrm{j}}\right)+\left(\overline{\mathrm{GJT}}_{\mathrm{j}}-\alpha_{\mathrm{j}}\right)$ where $\alpha_{\mathrm{j}}$ is a correcting factor introduced in order to get the true, non observable, reallocation value. The correction coefficient affects $\mathrm{CH}$ and GJT in the same measure, as the error is symmetric by definition and, as a result, the relation between $\mathrm{CH}$ and GJT is underestimated as the covariance between the two is distorted due to$$
\begin{aligned}
& \operatorname{Cov}\left(\mathrm{CH}_{\mathrm{j}}, \mathrm{GJT}_{\mathrm{j}}\right)=\operatorname{Cov}\left[\left(\overline{\mathrm{CH}}_{\mathrm{j}}+\alpha_{\mathrm{j}}\right),\left(\overline{\mathrm{GJT}}_{\mathrm{j}}-\alpha_{\mathrm{j}}\right)\right]= \\
& \operatorname{Cov}\left(\overline{\mathrm{CH}}_{\mathrm{j}}, \overline{\mathrm{GJT}}_{\mathrm{j}}\right)-\mathrm{s}_{\mathrm{a}}^{2}+\operatorname{Cov}\left(\overline{\mathrm{GJT}}_{\mathrm{j}}, \alpha_{\mathrm{j}}\right)-\operatorname{Cov}\left(\overline{\mathrm{CH}}_{\mathrm{j}}, \alpha_{\mathrm{j}}\right)
\end{aligned}
$$

${ }^{15} \mathrm{~b}_{1}$ expresses the relation of total turnover to firms with different rates of growth, and is not of immediate interest here. A positive, declining, relation is expected as said before as firms move to a bigger (smaller) dimensions.
} 
coefficient the bigger is excess reallocation. As from our preliminary descriptive work and from available theoretical models of labour flows ciclycality (Nagypal, 2004; 2005a; 2005b; Shimer, 2005a; 2005b), we expect the value of $b_{0}$ to be positive and cyclical.

Let us discuss the behaviour of $\mathrm{b} 0$ in relation to the TT-GJT plane of previous figure 2 (right hand side).

In figure $2, \mathrm{~b}_{0}$ represents the position of point $\mathrm{A}$ along the TT line. $\mathrm{b}_{0}=0, \mathrm{~b}_{1}=1$ and means zero excess reallocation for all GJT (the lower boundary). $\mathrm{b}_{0}=2, \mathrm{~b}_{1}=$ - 1 means that worker turnover flow is explained entirely by excess reallocation (the upper boundary). $0<\mathrm{b}_{0}>1$ means positive excess reallocation values. For every time period equation 5 has been estimated (regression with robust standard errors, Appendix) and the corresponding values of $\mathrm{b}_{0}$ provide, given the appropriate controls, an estimate of the yearly excess reallocation (figure 5). ${ }^{16}$

When the economy is experiencing rapid growth, from 1984 to 1990 and in 199596 job seekers are mainly employed workers and excess reallocation reflects the growing job to job transitions. For a given level of job flow, worker flow is definitely higher in expansion than in depression. When demand is low (198283,1991-93), employees are keen in keeping their job, whatsoever they may be, and excess reallocation is reduced; as soon as employment increases at the aggregate level, more and more total flows represent replaced quits, and excess reallocation flows explain the larger part of total turnover.

The variations through time of the estimated values of $\mathrm{b}_{0}$ point to an amplification mechanism that goes from gross job turnover to total turnover. Excess reallocation in our territory, given appropriate controls, responds rapidly and amplifies economic shocks, represented by the employment variations.

Excess reallocation flows explain the interaction between on the job search and job variations. This interaction generates a strong internal propagation mechanism and the employed search increases the variability of unemployment (amplification mechanism). The historical data of figure 5 point to the fact that on the job search and job to job transitions vary positively with aggregate productivity shocks (which, in the standard model, is equal to market tightness) when comparing

\footnotetext{
${ }^{16}$ For space reason only GJT coefficient estimates are reproduced; other results are in the appendix.
} 
different equilibria for different aggregate productivity levels. They also show that the amplification mechanism embedded in our model shows up clearly when considering the response of the unemployment and the excess reallocation flows to changes in aggregate productivity, a rather important character of actual labour markets, neglected by what has become the standard theory of equilibrium unemployment, i.e., the Mortensen-Pissarides model (Mortensen and Pissarides, 1994; Pissarides, 2000). Moreover our estimates show that excess reallocation varies negatively and the unemployment rate varies positively with job destruction shocks. Shimer (2005) argues that a destruction shock induces a positive correlation between excess reallocation and unemployment in the standard model, in stark contrast with the data. In our model, on the other hand, a higher destruction rate discourages excess turnover, because it shifts the composition of searchers towards the unemployed or people with lower expectations.

These empirical results corroborate important theoretical intuitions at the basis of the theoretical models of cyclicality of hires, separation and job to job transitions recently advanced by Nagypal (2004; 2005a; 2005b) and Shimer (2005a; 2005b).

Figure 5. Excess reallocation estimate $\left(\hat{b}_{0}\right)$ and unemployment rate.

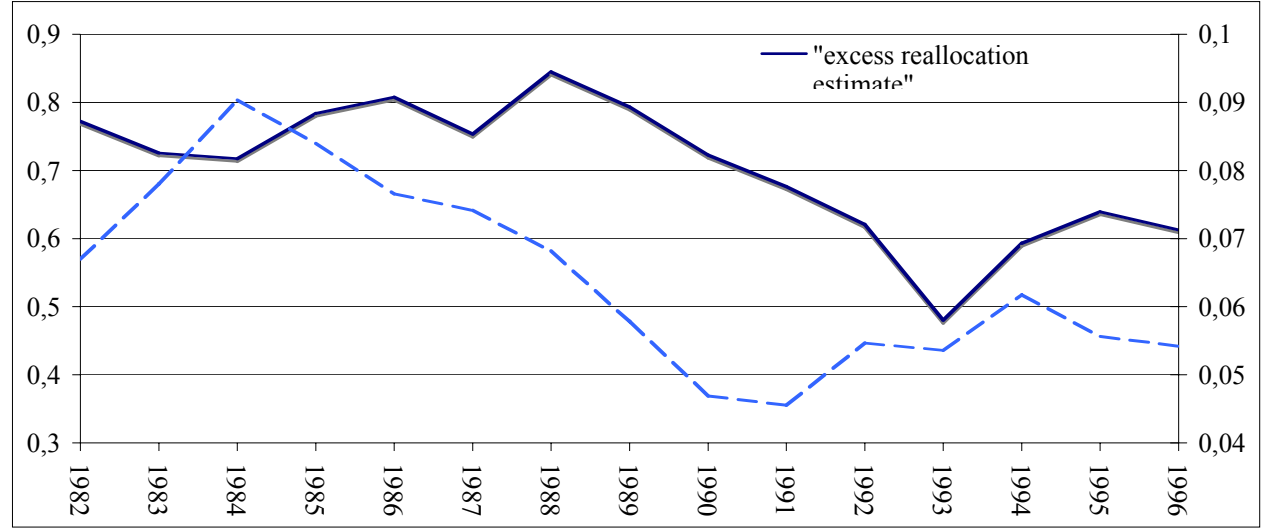

\section{$\underline{\text { 6. Conclusions. }}$}

Almost all the firms almost all the time are simultaneously hiring and experiencing separations. On average firms expand by raising their hiring and this move is often paralleled by an expansion in separations, as a substantial part of new hirings represent job to job transitions. Additionally many accessions end in a 
short period of time, either because they fill temporary jobs either because recently made matching are often revalued by both sides, workers and firms.

Using an informative employer-level panel we have studied the prevalence and cyclicality of excess reallocation, representing mainly job to job transitions. We have found that excess reallocation flows are vast and more than half of our firm's population face a labour turnover that is made by more than $50 \%$ by excess reallocation flows, i.e. workers move to a new employer conditional of not leaving the labour force. This means that studies looking only at flows between the states of employment, unemployment and out of the labour force largely underestimate the extent of mobility in the labour market.

With regard to cyclicality we challenge the traditional view among macroeconomists studying aggregate labour markets that high unemployment during recessions are due, to a large extent, to an increase in separation rates and that separations are countercyclical. Labour market cyclicality has its origin in the amplification mechanism explained by excess reallocation. Using estimation of the relation between total turnover and gross job turnover we explore the extent to which excess reallocation entails an amplification mechanism that helps in explaining the volatility of labour flows during the business cycle.

These results substantiate the need for a micro level analysis of employment adjustment and at the same time suggest that aggregate analysis of the labour market evolution through time offers important elements to understand the dynamic of labour flows.

\section{References}

Abowd. J, P.Corbell and F. Kramarz, 1999, The entry and exit of workers and the growth of employment: an analysis of French establishments. Review of Economics and Statistics. 81(2)

Albœk Karslen and Bent F. Sørensen, 1998, Worker Flows and Job Flows in Danish Manufacturing, 1980-91. Economic Journal, 108 (november)

Anastasia Bruno, Maurizio Gambuzza and Maurizio Rasera. 2000. La diffusione dei contratti a tempo determinato: il caso veneto. In Aris Accornero, a cura di, Solo una grande giostra? Franco Angeli: Milano. 61-188.

Bingley Paul, Tor Eriksson, Axel Werwatz, Niels Westergård Nielsen, 2000, Beyond "Manucentrism". Some Fresh Facts About Job and Workers Flows, mimeo. 
Boeri Tito, 1996, Is job turnover countercyclical? Journal of Labour Economics. 14(4). 603-625.

Burgess Simon, Julia Lane and David Stevens, 2000, Job Flows, Worker Flows and Churning. Journal of Labor Economics, v. 18, n. 3.

Burgess Simon, Julia Lane and David Stevens, 2001, Churning dynamics: an analysis of hires and separations at the employer level. Labour Economics. n. 8.

Contini Bruno and Riccardo Revelli, 1997, Gross Flows vs. net Flows in the Labour Market: What is there to be learned ? Labour Economics, 4, 245-263.

Davis Steven J. and John, C. Haltiwanger, 1992, Gross job creation, gross job destruction, and employment reallocation. Quarterly Journal of Economics. 107.3. 819-863.

Davis Steven J., John, C. Haltiwanger and Scott Schuh, 1996, Job Creation and Destruction, Cambridge: MIT.

Davis Steven and John C. Haltiwanger, 1999, Gross Job Flows, In O. Ashenfelter e D. Card, Handbook of Labour Economics. Vol. 3 Elesvier Science: Amsterdam.

Gerlach, Klaus L. and Wagner Joachim., 1993, Gross and net employment flows in manufacturing industries, Zeitschrift für Wirtschafts-und Sozialwissenschaften, vol.113.17-28.

Haltiwanger John, C. and Milan Vodopivec, 2002. Gross worker and job flows in a transition economy: an analysis of Estonia. Labour economics, vol.9(5), pp.601630 .

Leonard Jonathan, S. 1987, In the Wrong Place at the Wrong Time. In Lang K. and J.S. Leonard (eds.) Unemployment and the Structure of the Labour Market, Basil Blackwell:New York.

Leonard Jonathan, S. and Marc Van Audenrode, 1999, A Differende in Degree: Unemployment Despite Turnover in the Belgian Labour Market. Presented to the Venice meeting: Understanding the labour market. January.

Nagypál Eva, 2004, Worker Reallocation over the Business Cycle: The Importance of Job-to-Job Transitions, July 27.

Nagypál Eva, 2005a, Amplification of Productive Shocks: Why Don't Vacancies Like to Hire the Unemployed ? July.

Nagypál Eva, 2005b, On the Extent of Job-to-Job Transitions? September.

Occari Fabio and Serafino Pitingaro, 1997, Demografia di impresa e mobilità del lavoro: una stima della componente spuria sulla base degli archivi Inps. WP CNR, Occupazione e livelli di sttività in Italia.

Occari Fabio Giuseppe Tattara and Mario Volpe, 1997, Occupazione, mobilità e componente femminile nel mercato del lavoro: i lavoratori dipendenti a Treviso e

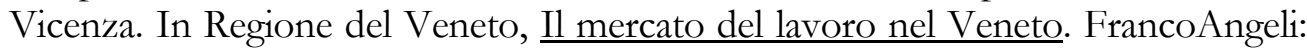
Milano, 460-488.

Occari Fabio Giuseppe Tattara and Mario Volpe, 2001, Gli archivi anagrafici Inps relativi ale imprese e ai lavoratori dipendenti. Appendice 1. In Giuseppe Tattara (a 
cura di). Il piccolo che nasce dal grande. le molteplici facce dei distretti industriali veneti. FrancoAngeli: Milano. 69-76.

OECD, 1999, OECD Employment Outlook. OECD: Paris.

Picot Garnett, Andrew Heisz and Alice Nakamura, 2001, Job tenure, worker mobility and youth labour market during the 1990s. WP. n 155. Statistics Canada. Business and Labour Market Analysis Division.

Rapiti Fabio, 1998, La misurazione e il significato del turnover occupazionale e i problemi di confrontabilità delle statistiche. Quaderni di ricerca ISTAT.n.3.

Revelli Riccardo, 1994, Statistics on job creation: issues in the use of administrative data. Conference on job creation and loss. Paris.

Schettkatt Ronald, 1996, Labour Markets Dynamics in Germany, in R. Schettkat (ed), The Flow Analysis of Labour Market, Routledge: London.

Tattara Giuseppe and Marco Valentini, 2005, La mobilità dei lavoratori dell'industria nel Veneto: dinamica di lungo periodo e aspetti differenziali, in B.Contini and U.Trivellato (eds.), Dinamiche e persistenze nel mercato del lavoro italiano. Il Mulino: Bologna. 
Appendix

In equation (6) $\mathrm{X}_{\mathrm{i}}$ is a vector of explanatory variables, controlling for observable heterogeneity:

size: firm size;

age: firm age;

young: ratio between employee $<30$ years old and total stock.

blue collar: ratio between blue collar and total stock;

gender: ratio between males and total stock;

temporary: ratio between training on the job (cfl) employees and apprentices to total employee;

season: ratio between seasonal workers and total stock;

dummies: artisan firms, sector (Ateco 3 digit), territory (local labour system: SLL).

Normalized variables are preferred to "level" variables in order to avoid the dimensional effect: TT depends on the firm structure, rather than on the absolute value of its characteristics.

Different models for growing and declining firms on population of continuing establishments from 1982 to 1996 have been estimated. The starting and closing years are excluded. Coefficients of 1993 and 1990 are in table 1A; other estimates are available on request.

\begin{tabular}{|c|c|c|}
\hline Variables & 1983 & 1990 \\
\hline GJT & $\begin{array}{r}0.1092221 \\
(0.0601741) \\
\end{array}$ & $\begin{array}{r}-0.0773138 \\
(0.0467086) \\
\end{array}$ \\
\hline GJT square & $\begin{array}{r}0.4672064 \\
(0.0605303) \\
\end{array}$ & $\begin{array}{r}0.6374797 \\
(0.0505554) \\
\end{array}$ \\
\hline size & $\begin{array}{r}-0.000469 \\
(0.0000912) \\
\end{array}$ & $\begin{array}{r}-0.0001631 \\
(0.0000782) \\
\end{array}$ \\
\hline size square & $\begin{array}{r}0.000000252 \\
(0.0000000684) \\
\end{array}$ & $\begin{array}{r}-0.0000000694 \\
(0.0000000808) \\
\end{array}$ \\
\hline age & $\begin{array}{r}0.0125153 \\
(0.0069155) \\
\end{array}$ & $\begin{array}{r}0.0094451 \\
(0.0026212) \\
\end{array}$ \\
\hline age square & $\begin{array}{r}-0.0023815 \\
(0.0006733) \\
\end{array}$ & $\begin{array}{r}-0.0009022 \\
(0.0001451) \\
\end{array}$ \\
\hline season & $\begin{array}{r}1.53386 \\
(0.0591345) \\
\end{array}$ & $\begin{array}{r}1.65686 \\
(0.0410046) \\
\end{array}$ \\
\hline gender & $\begin{array}{r}-0.0447542 \\
(0.0115446) \\
\end{array}$ & $\begin{array}{r}-0.0703747 \\
(0.0106907) \\
\end{array}$ \\
\hline young & $\begin{array}{r}-0.118635 \\
(0.0126967) \\
\end{array}$ & $\begin{array}{r}-0.1986939 \\
(0.0121538) \\
\end{array}$ \\
\hline temporary & $\begin{array}{r}0.1224221 \\
(0.0145948) \\
\end{array}$ & $\begin{array}{r}0.1280901 \\
(0.0133365) \\
\end{array}$ \\
\hline blue collar & $\begin{array}{r}-0.5159035 \\
(0.0223035) \\
\end{array}$ & $\begin{array}{r}-0.4122132 \\
(0.0161637) \\
\end{array}$ \\
\hline artisan & $\begin{array}{r}0.0714505 \\
(0.0075155) \\
\end{array}$ & $\begin{array}{r}0.0817135 \\
(0.0062661) \\
\end{array}$ \\
\hline dummy if $G J T=0$ & $\begin{array}{r}-0.1108671 \\
(0.0096683) \\
\end{array}$ & $\begin{array}{r}-0.1545955 \\
(0.0076687) \\
\end{array}$ \\
\hline sector 1 & $\begin{array}{r}0.0238638 \\
(0.0104753) \\
\end{array}$ & $\begin{array}{r}0.0550309 \\
(0.0088669) \\
\end{array}$ \\
\hline sector 2 & $\begin{array}{r}-0.0232483 \\
(0.0129367) \\
\end{array}$ & $\begin{array}{r}0.0032415 \\
(0.0121843) \\
\end{array}$ \\
\hline sector 3 & 0.0460966 & 0.0771035 \\
\hline
\end{tabular}




\begin{tabular}{|c|c|c|}
\hline & $(0.0098283)$ & $(0.0077128)$ \\
\hline sector 5 & $\begin{array}{r}-0.0193389 \\
(0.014022) \\
\end{array}$ & $\begin{array}{r}0.0078595 \\
(0.0109002)\end{array}$ \\
\hline sector 6 & $\begin{array}{r}0.0297275 \\
(0.013179)\end{array}$ & $\begin{array}{r}0.0590705 \\
(0.0119945) \\
\end{array}$ \\
\hline sector 7 & $\begin{array}{r}-0.0104207 \\
(0.0127798) \\
\end{array}$ & $\begin{array}{r}-0.0052675 \\
(0.0107801) \\
\end{array}$ \\
\hline sector 8 & $\begin{array}{r}-0.01218 \\
(0.0179452) \\
\end{array}$ & $\begin{array}{r}-0.0005177 \\
(0.0137825)\end{array}$ \\
\hline SLL 1 & $\begin{array}{r}0.0645013 \\
(0.0431659) \\
\end{array}$ & $\begin{array}{r}-0.0177614 \\
(0.0299654)\end{array}$ \\
\hline SLL 2 & $\begin{array}{r}0.0238966 \\
(0.0128774) \\
\end{array}$ & $\begin{array}{r}0.0306253 \\
(0.0118957) \\
\end{array}$ \\
\hline SLL 3 & $\begin{array}{r}0.0674182 \\
(0.0600888) \\
\end{array}$ & $\begin{array}{r}-0.0268925 \\
(0.0294916)\end{array}$ \\
\hline SLL 4 & $\begin{array}{r}0.0127318 \\
(0.0124755) \\
\end{array}$ & $\begin{array}{r}-0.0012259 \\
(0.010329)\end{array}$ \\
\hline SLL 5 & $\begin{array}{r}0.025134 \\
(0.0174848) \\
\end{array}$ & $\begin{array}{r}0.0182949 \\
(0.0143555) \\
\end{array}$ \\
\hline SLL 6 & $\begin{array}{r}-0.0174936 \\
(0.0173086) \\
\end{array}$ & $\begin{array}{r}0.0056162 \\
(0.0194171) \\
\end{array}$ \\
\hline SLL 7 & $\begin{array}{r}0.0061748 \\
(0.0144369) \\
\end{array}$ & $\begin{array}{r}-0.0096699 \\
(0.0126126)\end{array}$ \\
\hline SLL 8 & $\begin{array}{r}0.0103995 \\
(0.013131) \\
\end{array}$ & $\begin{array}{r}0.0112394 \\
(0.0127119) \\
\end{array}$ \\
\hline SLL 9 & $\begin{array}{r}0.0134701 \\
(0.0169649) \\
\end{array}$ & $\begin{array}{r}0.0008884 \\
(0.014853)\end{array}$ \\
\hline SLL 11 & $\begin{array}{r}0.012715 \\
(0.0172332) \\
\end{array}$ & $\begin{array}{r}-0.0081628 \\
(0.0128781)\end{array}$ \\
\hline SLL 12 & $\begin{array}{r}0.0458948 \\
(0.0163038) \\
\end{array}$ & $\begin{array}{r}0.0056324 \\
(0.0118621) \\
\end{array}$ \\
\hline SLL 13 & $\begin{array}{r}0.0177098 \\
(0.0129484) \\
\end{array}$ & $\begin{array}{r}0.0031188 \\
(0.011882) \\
\end{array}$ \\
\hline SLL 14 & $\begin{array}{r}0.0103134 \\
(0.0166277) \\
\end{array}$ & $\begin{array}{r}-0.001021 \\
(0.0132889) \\
\end{array}$ \\
\hline SLL 15 & $\begin{array}{r}0.0101434 \\
(0.0145234) \\
\end{array}$ & $\begin{array}{r}0.0214466 \\
(0.0146719) \\
\end{array}$ \\
\hline SLL 16 & $\begin{array}{r}0.0176667 \\
(0.0117379) \\
\end{array}$ & $\begin{array}{r}0.0230354 \\
(0.0100486) \\
\end{array}$ \\
\hline SLL 17 & $\begin{array}{r}0.0268691 \\
(0.0183315) \\
\end{array}$ & $\begin{array}{r}0.0081831 \\
(0.0166036)\end{array}$ \\
\hline Constant & $\begin{array}{r}0.7255904 \\
(0.0274125)\end{array}$ & $\begin{array}{r}0.722718 \\
(0.0189536)\end{array}$ \\
\hline
\end{tabular}

